\title{
THE ROLE OF CARCINOGENIC METALS IN THE FORMATION OF THYROID CANCER MORBIDITY IN THE POPULATION
}

\author{
Balenko N.V., Tsymbaliuk S.M., Chernychenko I.O., Lytvychenko O.M., Hulchii N.V, \\ Ostash O.M. \\ РОЛЬ КАНЦЕРОГЕНИХ МЕТАЛПВ У ФОРМУВНННІ ЗАХВОРЮВАНОСТІ
НАСЕЛЕННЯ НА РАК ЩИТОПОДББОї ЗАЛОЗИ
}

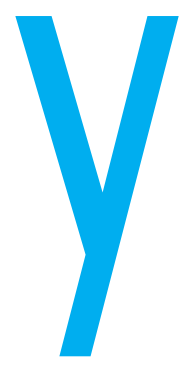

БАЛЕНКО Н.В. *ЦИМБАЛЮК С.М., ЧЕРНИЧЕНКО I.O. ЛИТВИЧЕНКО О.М., *ГУЛЬЧІЙ М.В. ОСТАШ O.M.

ДУ «ІГЗ ім. О.М. Марзєєва

HAMHУ», м. Київ

*Київський міський клінічний ендокринологічний центр

УДК $614.71: 616-006: 616.441$

Ключові слова: рак щитоподібної залози, хром, кадмій, нікель, свинець, атмосферне повітря, механізми дії, огляд літератури. попередніх дослідженнях нами встановлено наявність достовірного кореляційного зв'язку між забрудненням повітря міст з різним характером промислового розвитку (м. Київ, м. Черкаси) пріоритетними хімічними канцерогенами різних класів, у тому числі важкими металами (ВМ - хром, нікель, кадмій, свинець), і захворюваністю населення на рак щитоподібної залози (РЩЗ). Показано, що серед металів найбільший вплив на формування онкозахворюваності чинять хром та кадмій $[1,2]$.

Мета роботи - визначення можливих механізмів впливу канцерогенних металів атмосферних забруднень на формування захворюваності населення на РЩЗ

Матеріали та методи: аналіз власних та літературних даних. Використано метод теоретичного аналізу науково-методичної літератури (узагальнення, синтез та абстрагування) стосовно особливостей біоефектів досліджуваних металів та закономірностей їхніх проявів [3]
Результати роботи та їx обговорення. Як відомо, ВМ пріоритетні забруднювачі довкілля (зокрема атмосферного повітря), які за масштабами впливу на людину, згідно з визначенням експертів ВООЗ, поступаються тільки пестицидам та радіоактивним забруднювачам [4].

Необхідно зазначити, що у реалізації впливу на організм особливе значення надається саме інгаляційному шляху надходження ВМ [4, 5]. 3 одного боку, завдяки великій контактній поверхні легенів (90-100 м²) він забезпечує максимальну абсорбцію концентрації металів, які надходять з забрудненим повітрям, може сприяти більш ефективній кумуляції та збільшенню внутрішньої діючої дози. 3 іншого боку, інгаляційний шлях, на відміну від перорального, сприяє надходженню токсикантів безпосередньо у кров'яне та лімфатичне русла, оминаючи основний орган детоксикації (печінку), що, очевидно, посилює їхній нега-
РОЛЬ КАНЦЕРОГЕННЫХ МЕТАЛЛОВ В ФОРМИРОВАНИИ ЗАБОЛЕВАЕМОСТИ НАСЕЛЕНИЯ РАКОМ ЩИТОВИДНОЙ ЖЕЛЕЗЫ

Баленко Н.В., *Цимбалюк С.Н., Черниченко И.А., Литвиченко О.Н., *Гульчий Н.В., Осташ О.М. ГУ «ИОЗ им. А.Н. Марзеева НАМНУ», Г. Киев ${ }^{\star}$ Киевский городской клинический эндокринологический центр

Цель работы - определение возможных меха низмов влияния приоритетных канцерогенных металлов атмосферных загрязнений (хром, никель, кадмий, свинец) на формирование заболеваемости населения раком щитовидной железы.

Методы. Использован метод теоретического анализа (обобщение, синтез, абстрагирование) литературных и собственных данных, касающихся особенностей биоэффектов канцерогенных металлов и закономерностей их проявления.

Результаты проведенного анализа позволяют предположить, что исследуемые канцерогенные металлы при хроническом комбинированном поступлении в организм, вызывая многочисленные эффекты на разных уровнях (молекулярном, биохимическом, органном, системном), могут оказывать влияние на формирование заболеваемости населения раком щитовидной железы двумя путями: 1 - путем индукции прямых и непрямых (оксидативных) повреждений ДНК и эпигенетических нарушений в неизменных тиреоцитах с последующим развитием нестабильности генома, возникновением мутаций, рака; 2 - путем индукции аналогичных повреждений в первоначально вызванных узловых образованиях (струмогенный эффект), пролиферирующие клетки которых представляют чувствительный морфологический субстрат для их возникновения.

Длительное существование комплекса этих изменений на фоне нарушений функций иммунной системы, присущих всем металлам, может способствовать росту риска и ускорению развития злокачественных опухолей щитовидной железы среди населения.

Ключевые слова: рак щитовидной железы, хром, кадмий, никель, свинец, атмосферный воздух, механизмы действия, обзор литературы.

() Баленко Н.В., Цимбалюк С.М., Черниченко І.О., Литвиченко О.М., Гульчій М.В., Осташ О.М. СТАТТЯ, 2017. 
THE ROLE OF CARCINOGENIC METALS IN THE FORMATION OF THYROID CANCER MORBIDITY IN THE POPULATION

Balenko N.V., *'Tsymbaliuk S.M., Chernychenko I.O., Lytvychenko O.M., *Hulchii N.V., Ostash O.M.

State Institution "O.M. Marzeiev Institute for Public Health National Academy of Medical Sciences of Ukraine", Kyiv

${ }^{*}$ Kyiv City Clinical Endocrinology Centre Objective. We determined the possible mechanisms of the effect of the foreground carcinogenic metals of the atmospheric pollutions (chrome, nickel, cadmium, lead) on the formation of thyroid cancer morbidity in the population.

Materials and methods. We used a method of theoretical analysis (generalization, synthesis, abstraction) of literary data and our investigation data concerning with the peculiarities of the bioeffects of carcinogenic metals and regularities of their manifestation.

Results. The results of the performed analysis allow us to consider that metals, under chronic combined intake into the organism, resulting in numerous effects at various levels (molecular, biochemical, organ, systemic), can affect the formation of thyroid cancer morbidity in the population by two ways: 1 - by means of the induction of direct and indirect (oxidative) DNA damages and epigenetic disorders in unchanged thyrocytes with a further development of genome instability, beginning of mutations, cancer; 2 - by means of the induction of similar damages in the primary induced knot neoplasms (goitrogenic effect), their proliferating cells are a sensitive morphological substratum for their beginning. Prolonged existence of the complex of these changes against a background of the disorders of the immune system functions, typical for all metals, can encourage a risk of the growth and the acceleration of the development of the malignant tumors of thyroid glands among the population.

Keywords: thyroid cancer, chromium, cadmium, nickel, lead, atmospheric air, mechanisms of influence. тивний вплив на організм загалом та органи зокрема.

Відмінною рисою цих токсикантів $€$ здатність до матеріальної кумуляції та прояву віддалених у часі ефектів.

За даними експериментальних та епідеміологічних досліджень, ВМ та їхні сполуки індукують пухлини у лабораторних тварин та спричиняють злоякісні захворювання у людей за умов професійного впливу [6, 7].

Характерним для них $є$ прояв канцерогенного ефекту у тропних органах та органах переважного депонування. При цьому метали характеризуються політропною дією, суттєво впливаючи на різні системи організму, у тому числі ендокринну систему [4, 5, 8-12]. Останнє стало підставою для включення їх експертами В003 та ОOH до переліку «хімічних руйнівників ендокринної системи» (ХРЕС), тобто хімічних сполук, що несприятливо впливають на органи ендокринної системи [13].

На думку експертів, ВМ в цілому порушують гормональні шляхи в організмі. Припускається, що основними мішенями для них можуть бути рецептори стероїдних гормонів, а також рецептори гормонів щитоподібної залози (ЩЗ).

Водночас механізми впливу на ЩЗ і канцерогенез зокрема залишаються маловивченими.

З точки зору оцінки можливого впливу металів на виникнення РЩЗ серед населення важливе значення, на нашу думку, мають встановлені на цей час спільні для них властивості та закономірності дії.

Доведено, що ВМ за надходження до організму у низьких дозах справляють переважно адитивний ефект, тоді як великі дози можуть проявляти антагонізм.

Встановлено, що ВМ є блокаторами SH-груп та антагоністами селену, надзвичайно важливого для організму мікроелемента. Блокада селену ВМ здійснюється шляхом утворення з ним стійких комплексів, що робить його біологічно недоступним та створює вторинний селенодефіцит [14].

Зазначені закономірності прояву біоефектів за дії малих доз дозволяють припустити, що комбіноване надходження металів може призвести до адитивної блокади SH-груп білків та селену.

Дефіцит селену негативно впливає на функцію ЩЗ, оскільки він входить до складу ферментів тиреоїддейодиназ, які регулюють активність тироксину $\left(\mathrm{T}_{4}\right)$ та здійснюють його конверсію у трийодтиро$\mathrm{HiH}\left(\mathrm{T}_{3}\right)$.

Як відомо, безпосередньо у ЩЗ синтезується тільки частка (до 20\%) фізіологічно необхідного $\mathrm{T}_{3}$ [13]. Решта гормону утворюється за рахунок дейодинізації тироксину ферментами у різних периферичних тканинах (печінка, нирки, кишківник, шкіра, матка, головний та спинний мозок, гонади й ін.). У зв'язку з цим затримка металів у цих органах та зв'язування селену можуть пригнічувати активність ферментів, що, у свою чергу, призводить до порушення метаболізму тиреогормонів та виникнення їхньої недостатності (гіпотиреозу).

Недостатність селену не тільки погіршує прояви йодного дефіциту, що призводить до гіпотиреозу, а й викликає морфологічні ушкодження залози (некроз, фіброз), стимулюючи клітинну проліферацію [14]. Крім того, дефіцит селену пов'язаний зі зростанням захворюваності на аутоімунний тиреоїдит (AIT), який також призводить до гіпотиреозу внаслідок ушкодження та зменшення кількості функціонально активних клітин у щЗ.

Отже, завдяки наявності спільних ефектів наслідком комбінованої дії металів і їхніх сполук на щз, вірогідно, може бути адитивний неканцерогенний ефект, що проявляється порушенням функції ЩЗ за типом гіпотиреозу і виникає у результаті розладу гормоноутворення внаслідок йододефіциту через перешкоджання надходження йоду до щитоподібної залози та порушення метаболізму тиреогормонів через зв'язування селену ВМ у різних органах, порушення функціонування тиреогормонів при взаємодії їх з рецепторами, а також запуску захворювань на AIT. Тривала недостатність функції ЩЗ стимулює продукцію гіпофізом тиреостимулюючого гормону та викликає проліферацію тиреоцитів з наступним розвитком гіперплазії ЩЗ, зоба, а також нодозних утворень на тлі AIT тощо. 
бачити ще й інші механізми впливу на ЩЗ, додатково до наведених спільних.

Зокрема, до металів, що можуть спричинити оксидативні ушкодження ДНК у тиреоцитах, належить хром, есенціальний мікроелемент, який бере участь у здійсненні багатьох важливих функцій в організмі, у тому числі регулює функцію ЩЗ шляхом взаємодії з йодом [19].

Разом з тим, як і інші мікро-

В аспекті канцерогенезу у щ3 привертає увагу спільна властивість досліджуваних ВМ - прооксидантна активність, тобто здатність викликати утворення активних форм кисню (АФК), вільних радикалів, що проявляється оксидативним стресом. Вважається, що це можливо тільки за дії високих концентрацій і $є$ одним 3 механізмів, що визначають токсичність і канцерогенність BM $[6,8,15]$. Проте цілком логічно припустити, що внаслідок адитивного впливу, притаманного дії малих доз, цей ефект може реалізуватися у щ3 за рахунок накопичування тих металів, що здатні затримуватися у залозі при комплексному надходженні до організму. Згідно з сучасними уявленнями збільшення внутрішньоклітинного рівня АФК може спричинити окисне пошкодження ДНК з наступним виникненням мутацій. Загалом АФК підвищують ймовірність злоякісної трансформації клітин, формуючи генетичну нестабільність, і впливають на канцерогенез на стадії ініціації та промоції [15-18].

Нині доведено, що зоб, АІT супроводжуються активацією вільнорадикальних процесів в ураженій тканині ЩЗ, що збільшує ймовірність оксидативного ушкодження ДНК та виникнення мутацій. Хронічний перебіг цих захворювань за одночасного тривалого впливу ВМ та індукованих ними прооксидантних змін у поєднанні з притаманним їм пригніченням активності системи антиоксидантного захисту (АОC) є сприятливим тлом для виникнення і накопичування мутованих клітин, їхньої трансформації і появи раку. До того ж проліферуючі клітини є особливо чутливими до таких змін.

Враховуючи специфічність кожного з ВМ, можна перед- елементи [14, 20], хром характеризується вузьким діапазоном біологічної дії. Тому і дефіцит, і надлишок його в організмі можуть спричинити розвиток різноманітних порушень і патологічних станів [19].

Встановлено, що хром та його сполуки після надходження до організму затримуються, окрім інших органів, також у щ3, що може зумовити поступове накопичення в органі за умови тривалого вдихання 3 забрудненим повітрям. 3 одного боку, таке накопичення може призвести до порушення співвідношення 3 йодом та перешкоджає його засвоєнню з наступним зниженням синтезу та рівня тиреогормонів, що врешті-решт викликає гіперплазію ЩЗ, розвиток зоба. Такий хід процесів підтверджують дані про кореляцію підвищених рівнів сполук хрому та порушення їх співвідношення $з$ іншими металами у навколишньому середовищі з поширеністю зоба серед населення [21]. При цьому вказується, що надлишок хрому сприяє посиленню йододефіциту.

3 іншого боку, кумуляція сполук хрому у ЩЗ може створити небезпеку утворення у процесі метаболізму безпосередньо у тиреоцитах АФК та вільних радикалів додатково до кількості, яка завжди утворюється під час гормоноутворення (окиснення, органіфікація йодидів) завдяки участі тиреопероксидази [22, 23].

Як вже було вказано, збільшення сумарної концентрації їх у тиреоцитах за умов пригнічення АOC може зумовити зростання ймовірності оксидативного ушкодження ДНК 3 наступним формуванням нестабільності генома, виникненням мутацій та злоякісної трансформації тиреоцитів і сприятиме ініціації канцерогенезу та зростанню ризику
РЩЗ. Мутації у тиреоцитах можуть виникати також внаслідок прямого ушкодження ДНК через здатність хрому утворювати адукти «хром-ДНК» [24].

Накопиченню індукованих мутацій і наступній пухлинній трансформації клітин певною мірою може сприяти притаманна сполукам хрому відмінна риса - здатність ушкоджувати клітинну систему репарації помилок реплікації, причому навіть за дії на рівні низьких доз [24]. Особлива небезпека індукції клітин з ушкодженою системою репарації визначається тим, що вони мають високий мутаційний потенціал та стійкість до апоптозу, які зберігаються навіть після припинення впливу металу.

Дослідження останніх років показали важливу роль у канцерогенезі гормональних органів епігенетичних змін (порушення процесів метилювання ДНК, модифікація гістонів, експресія мікроРНК) $[13,25]$.

Останнім часом з'явилися повідомлення також про роль епігенетичних механізмів і у розвитку РЩЗ та можливість використання їх для розробки методів мішеневої терапії [26-29].

Епігенетичні механізми канцерогенезу, індукованого хроматами, донині залишаються маловивченими.

Нікель, за даними літератури, розглядається як токсичний або умовно есенціальний мікроелемент [6, 14, 30].

Потрапляючи до організму, сполуки нікелю затримуються у легенях та більш-менш рівномірно - в інших органах, передусім у наднирниках та щитоподібній залозі, де вміст їх у 10 разів вищий і свідчить про можливість накопичення у цих органах [8].

Подібно до інших металів сполуки нікелю також здатні індукувати утворення АФК і вільних радикалів, зв'язувати селен та SH-групи.

На відміну від хрому, для якого доведено визначальну роль у канцерогенезі прямого та оксидативного ушкодження ДНК, у канцерогенезі, індукованому нікелем, домінуюче значення надається епігенетичним механізмам [24, 25, 30]. Це аргументується наявністю високої канцерогенної активності нікелю, незважаючи на відсутність або низьку мута- 
генність його сполук у більшості мутагенних тестів.

Експериментально доведено, що в основі шкідливих ефектів сполук нікелю (зокрема канцерогенного) початковим $\epsilon$ порушення процесів метилювання ДНК та гетерохроматинових ділянок хроматину.

3'являється все більше доказів, що демонструють порушення ДНК-метилювання та деацетилювання гістонів як два основних типи ефектів у клітинах ссавців за експозиції до сполук нікелю.

Ці ефекти спричиняють інактивацію низки генів супресорів пухлин та генів старіння, яка може сприяти пухлинній трансформації і спостерігається у різних новоутвореннях людей [24-26]. Ці дані є підставою думати про можливість таких ефектів за дії сполук нікелю на ЩЗ.

Встановлено, що за хронічного надходження до організму 3 хромом сполуки нікелю проявляють синергічний ефект.

У контексті посилення канцерогенного ефекту, на нашу думку, одним із факторів, що сприяють цьому, може бути виявлена здатність сполук нікелю до активації сигнальних шляхів гіпоксії через взаємодію з транскрипційними факторами, що регулюють гени, пов'язані з розвитком гіпоксійних станів [24]. Ініціювання стану гіпоксії цими сполуками може створити сприятливі умови для селекції клітин 3 ушкодженим енергетичним метаболізмом, зміненим контролем росту або стійких до апоптозу, які виникають внаслідок сумісної дії сполук обох металів.

Підсилення канцерогенного ефекту може відбуватися також завдяки здатності сполук нікелю пригнічувати процеси репарації ушкоджень ДНК, що призводить до накопичення мутацій. На це вказують дані про комутагенні властивості нікелю [6, 7, 24].

Наведені факти дозволяють припустити, що нікель може давати певний внесок у сумарний ефект металів на ЩЗ через деякі, притаманні тільки йому механізми, а також аналогічні для хрому та спільні для ВМ механізми і таким чином сприяти зростанню ризику РЩЗ.
На відміну від сполук хрому та нікелю кадмій і його сполуки не належать до есенціальних і однозначно вважаються небезпечними забруднювачами виробничого середовища довкілля [6, 8-11]. Для них характерні висока біологічна активність і токсичність, здатність до кумуляції та індукції утворення вільних радикалів.

Як і інші метали, сполуки кадмію - антагоністи селену та цинку, їм властива висока спорідненість до SH-груп.

Вказані ефекти можуть вести до зниження функції синтезу білків у печінці, у тому числі тироксинзв'язувальних транспортних, а також до пригнічення активності ферментів дейодиназ у різних органах. Наслідком цього, як і за дії інших металів, може бути недостатність тиреогормонів в організмі та порушення функції ЩЗ за типом гіпотиреозу, що дає певний внесок та поглиблює сумарний ефект металів.

Крім зазначених, у тому числі спільних для металів механізмів, у реалізації гіпотиреозу за дії сполук кадмію, на нашу думку, певну роль можуть відігравати механізми, пов'язані 3 наявністю у них естрогеноміметичних властивостей. Діючи подібно до естрогенів, кадмій здатний активувати рецептори естрогенів.

Як відомо, більшу частоту вузлових захворювань і раку ЩЗ у жінок пов'язують саме 3 дією естрогенів та естрогеноміметичних хімічних сполук на рецептори естрогенів, що задіяні у клітинних процесах, причетних до посилення мітогенних, міграційних та інвазивних властивостей тиреоїдних клітин [13].

Експериментально доведено, що естрогени посилюють проліферацію тиреоцитів, знижуючи поглинання йоду через пригнічення експресії натріййод-симпортера, який здійснює транспорт йоду у тиреоцити. Причому встановлено, що експресія цього ферменту регулюється епігенетичними механізмами - метилюванням промотора гена. Крім того, естрогени впливають на функцію ЩЗ, підвищуючи концентрацію тироксинзв'язуючого глобуліну у крови, що поглиблює зниження рівня вільного тироксину [31].
Урахування наведених даних дозволяє припустити можливість струмогенного впливу сполук кадмію на ЩЗ та виникнення раку завдяки зазначеним спільним для ВМ властивостям та притаманній їм естрогеноміметичній активності.

I нарешті, ще один шлях впливу сполук кадмію на ЩЗ пов'язаний 3 властивою їм разом з естрогенною активністю також андрогенною та антиандрогенною дією, що може спричинити порушення гормональних шляхів і взаємодію їх. Ці ефекти лежать в основі механізмів індукції передміхурової залози [13], а також розглядаються багатьма фахівцями як один з факторів ризику РЩЗ.

За даними літератури, свинець та його сполуки належать до високотоксичних ксенобіотиків, яким властива політропна дія [5, 6, 8-10, 12, 15, 32].

Так, свинець має високу спорідненість з сульфгідрильними групами (SH-), є антагоністом селену, наслідком чого може бути порушення метаболізму тиреогормонів та зниження активності АOC.

Це підтверджено і в епідеміологічних дослідженнях, які свідчать про зниження концентрації глютатіону та активності ферментів АОС у робітників, професійно експонованих до свинцю.

Низка біоефектів, індукованих сполуками свинцю, $€$ подібними до біоефектів, індукованих радіоактивним випромінюванням (ушкодження клітинних мембран, зниження рівня функціонально активних груп клітинних протеїнів, пригнічення репарації ДНК, порушення метаболізму глютатіону тощо). Це стало приводом вважати їх речовинами, що мають радіоміметичні властивості [5].

Сполуки свинцю можуть впливати також на стан ЩЗ, проявляючи струмогенний ефект [5, 21, 33]. Це підтверджується кореляцією поширеності зоба та набутого гіпотиреозу з підвищеними рівнями забруднення навколишнього середовища свинцем разом 3 іншими металами (міддю, молібденом). Крім того, потрапляючи у тканину щЗ, свинець зв'язується 3 білками та спричиняє розвиток аутоімунних реакцій в органі. 
Наявність доказів про затримку свинцю у головному мозку та розлади функції гіпоталамо-гіпофізарно-надниркової системи можуть свідчити, на нашу думку, про те, що в основі струмогенного ефекту разом з іншими спільними для металів механізмами лежить також порушення синтезу тиреогормонів на регуляторному рівні. Адже відомо, що гіпофіз та гіпоталамус $\epsilon$ регуляторами гормоноутворення у ЩЗ.

Слід зазначити, що реалізації онкогенного ефекту металів у Щ3 може сприяти також імунотоксичність, яка є їхньою спільною властивістю. Численні дослідження, кількість яких продовжує зростати, свідчать про супресивний вплив металів на клітинну і гуморальну ланки імунітету [6, 8, 34, 35].

Загальновизнаною $є$ роль імунної системи у канцерогенезі, розлади якої розглядаються як ендогенний фактор високого ризику виникнення раку. Пригнічення функції різних її компонентів та порушення взаємодії між ними сприяють збереженню, виживанню трансформованих клітин та формуванню злоякісних новоутворень.

Отже, проведене аналітичне вивчення наукової інформації у

Схема можливих шляхів впливу металів (хром, нікель, кадмій, свинець) на виникнення раку щитоподібної залози за комбінованого надходження до організму з забрудненим повітрям

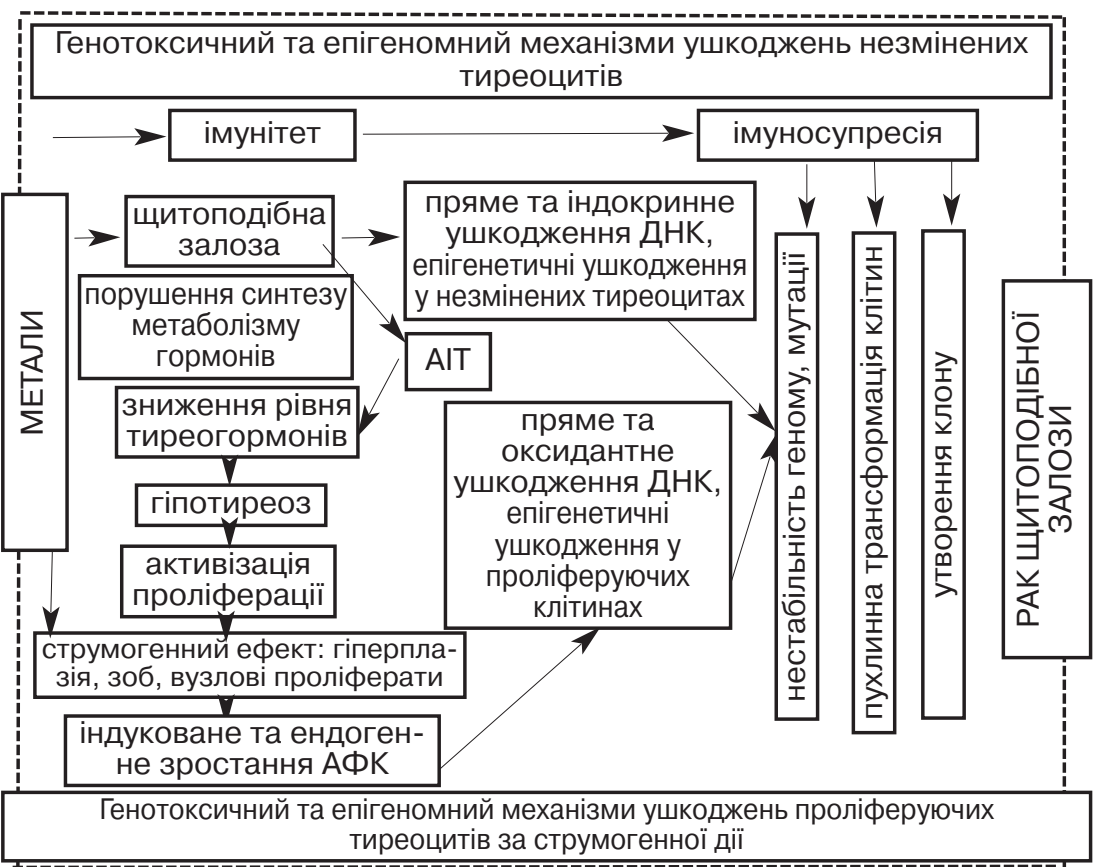

Примітки: АIT - аутоімунний тиреоїдит;

АФК - активні форми кисню. кісних пухлин ЩЗ. контексті досліджуваного питання свідчить про розрізненість та обмеженість даних щодо розуміння механізмів впливу канцерогенних металів на виникнення і розвиток злоя-

Разом 3 тим теоретичний аналіз накопиченого донин фактичного матеріалу дозволяє сформулювати цілісну концепцію впливу ВМ на формування захворюваності населення на РЩЗ, яку можна зобразити у вигляді гіпотетичної схеми (рис.).

Як бачимо, за комбінованого надходження ВМ (хром, кадмій, нікель, свинець) здатні впливати на Щз через різноманітні механізми на молекулярному, біохімічному, клітинному, органному та системному рівнях, викликаючи каскад змін, які умовно можна поділити на два типи.

Перший тип - це зміни, що можуть відбуватися у тиреоцитах через залучення генетичних та епігенетичних механізмів і передують злоякісним пухлинам.

Генетичні механізми реалізуються шляхом прямих і непрямих (оксидативних) ушкоджень ДНК з наступним формуванням генетичної нестабільності та виникненням мута-

Рисунок

\section{,} процино-гіперпластичних лового зоба, аденом тощо (струмогенний ефект).

Довготривала проліферація тиреоцитів як така $€$ певною детермінантою мутацій і разом з тим чутливим морфологічним субстратом для виникнення генетичних та епігенетичних змін через дію канцерогенних металів і подальший добір клону трансформованих клітин. Поєднання наведених двох типів ефектів, викликаних металами, може сприяти пришвидшенню та збільшенню ймовірності злоякісної трансформації тиреоцитів і появі раку.

у цьому контексті привертають увагу нові дані про те, що мутації і проліферація - процеси скоординовані. Селективні мутації онкогенів породжують нові шляхи передавання сигналів, що сприяє проліферації клітин, у результаті - посилена 
проліферація ще більше прискорює швидкість мутацій [36]. Зрозуміло, що такі зміни можуть збільшити ризик виникнення РЩЗ.

Тобто метали викликають різноманітні зміни на різних рівнях, які забезпечують формування генетичної нестабільності, порушення енергетичного метаболізму та активацію проліферації тиреоцитів за одночасного послаблення імунного контролю, що характеризує пухлинний ріст.

Отже, можливі два шляхи виникнення раку - через накопичення генетичних прямих і непрямих ушкоджень 3 залученням епігенетичних змін у тиреоцитах та через індукцію цих саме змін у проліферуючих клітинах індукованих металами вузлових захворювань (зоб, АІT тощо). Очевидно, що внесок окремих металів у сумарний канцерогенний ефект залежить не лише від типу та кількості індукованих ними біоефектів, а й від рівня забруднення цими речовинами та співвідношення між ними.

Варто підкреслити, що передбачувані механізми впливу металів на формування захворюваності населення на РЩЗ цілком узгоджуються 3 встановленим нами позитивним кореляційним зв'язком між показниками онкозахворюваності населення і забрудненням атмосферного повітря металами.

Більш того, прогнозовані різні механізми дії металів можна характеризувати як специфічні для канцерогенезу (генотоксичні та епігенетичні), що відіграють етіологічну роль, та неспецифічні токсичні ушкодження (порушення процесів синтезу, транспорту, метаболізму тиреогормонів, ушкодження морфологічної структури, формування гіпоксійного стану з наступною гіпофункцією та проліферативногіперпластичними змінами), які належать до патогенетичних, сприяють канцерогенезу і його модифікації, відповідають виявленому нами кореляційному зв'язку захворюваності населення на РщЗ не тільки 3 показниками канцерогенного ризику, а й з показниками неканцерогенного ризику. Останнє підтверджує можливість розвитку РЩЗ також через стадію попередньо індукованих металами вузлових захворювань залози, які багатьма фахівцями розглядаються як передракові.

Таким чином, результати проведеного аналізу джерел наукової інформації дозволяють шляхом узагальнення даних передбачити ймовірність впливу металів на виникнення і розвиток злоякісних пухлин щЗ та визначити необхідність подальших досліджень у цьому напрямку.

\section{Висновки}

Виявлено два типи змін за комбінованого надходження канцерогенних металів (хром, нікель, кадмій, свинець) до організму 3 атмосферними забрудненнями, які можуть впливати на формування захворюваності на рак щитоподібної залози.

Перший тип - це специфічні для канцерогенезу зміни, що можуть відбуватися у тиреоцитах 3 включенням генетичних та епігенетичних механізмів, передують злоякісним пухлинам і відіграють етіологічну роль. У результаті генетичних та епігенетичних змін виникають мутації, відбувається пухлинна трансформація тиреоцитів 3 подальшим клональним добором цих клітин, що завершується виникненням раку ЩЗ. Зазначені зміни стосуються переважно металів (хром, нікель), здатних затримуватися та накопичуватися безпосередньо у тканині щЗ.

Другий тип змін може виникати завдяки токсичній дії усіх вивчених ВМ і пов'язаний зі змінами на різних рівнях організації організму, що можуть спричинити порушення різних етапів синтезу та регулювання гормонів, їх транспорту, метаболізму та функціонування, запуск аутоімунних захворювань (AIT). Кінцевим результатом цих процесів $€$ зниження функції ЩЗ за типом гіпотиреозу з подальшим розвитком проліферативно-гіперпластичних процесів, гіперплазії щ3, вузлових утворень (струмогенний ефект), проліферуючі клітини яких є чутливим морфологічним субстратом для індукування генетичних, епігенетичних змін канцерогенними металами, сприяють формуванню клону трансформованих клітин і мають патогенетичне значення. Поєднання наведених двох типів ефектів на тлі порушень індукованого металами імунного стану може сприяти збільшенню та пришвидшенню ймовірності злоякісної трансформації тиреоцитів і появи раку.

Можливі два шляхи виникнення раку: через накопичення генетичних прямих та непрямих ушкоджень ДНК і залучення епігенетичних змін у незмінених тиреоцитах та через індукцію аналогічних змін у проліферуючих клітинах попередньо індукованих металами вузлових утворень ЩЗ (гіперплазія ЩЗ, зоб, AIT тощо) на тлі імуносупресії.

ЛІТЕРАТУРА

1. Литвиченко О.Н., Черниченко И.А., Цимбалюк С.Н. Влияние приоритетных химических канцерогенов атмосферного воздуха на заболеваемость населения раком щитовидной железы Здоровье и окружающая среда: сб. науч. тр. Минск, 2015. Т. І, вып. 25. С. 55-58.

2. Черниченко І.О., Литвиченко О.М., Цимбалюк С.М., Швагер О.В., Соверткова Л.С. Баленко Н.В. Хімічні канцерогени атмосферного повітря: вплив на захворюваність населення на рак щитоподібної залози. Гігієна населених місць: зб. наук. праць. Київ, 2015. Вип. 66. С. 104-110.

3. Басков А.Я., Туленков Н.В. Методология научного исследования. К. : МАУП, 2004. 215 c.

4. Сердюк А.М., Белецкая Э.Н., Паранько Н.М., Шматков Г.Г. Тяжелые металлы внешней среды и их влияние на репродуктивную функцию женщин. Днепропетровск : Арт-Пресс, 2004. 148 с.

5. Трахтенберг И.М. Тяжелые металлы как химические загрязнители производственной и окружающей среды. Довкілля та здоров'я. 1997.

№ 2. C. 48-51.

6. Environmental and Occupational Medicine / Ed. By W.N. Rom. - Philadelfia. NewYork, 1998. 1437 p.

7. JARC Monographs on the Evaluation of the Carcinogenic Risks to Humans. Arsenic, Metals, Fibers and Dusts. Lyon: IARC, 2012. Vol. 100.

P. 41-467.

8. Общая токсикология / под ред. Б.А. Курляндского, В.А. Филова. М. : Медицина, 2002. 608 c. 
9. Транхтенберг И.М., Колесников В.С., Луковенко В.П. Тяжелые металлы во внешней среде: современные гигиенические и токсикологические аспекты. Минск : Наука и техника, 1994. 285 с

10. Трахтенберг І.М. Чекман I.C., Линник В.О., Каплуненко В.Г., Гуліч М.П. Білецька Е.М., Шаторна В.Ф., Онул Н.М. Взаємодія мікроелементів: біологічний, медичний і соціальний аспекти. Вісник НАН України. 2013. № 6. C. 11-20.

11. Дмитруха Н.М. До питання нефротоксичної дії кадмію. Український журнал з проблем медицини праці. 2010. № 2 (22). С. 36-41.

12. Петринич В.В. Характер токсичних ефектів у щурів 3 різною швидкістю ацетилювання за умов підгострого впливу марганцю хлориду і свинцю ацетату та профілактика за допомогою кверцетину : автореф. дис. канд. мед. наук. Київ, 2013. 22 с

13. WHO/UNEP State of the Science of Endocrine Disrupting Chemicals. 2012 :

An assessment of the state of the science of endocrine disruptors prepared by a group of experts for the United Nations Environment Programme (UNEP) and WHO. URL : http://www.who.int/ceh/publications/endocrine/en/

14. Білецька Е.М., Онул Н.М. Селен у довкіллі: еколого-гігієнічні аспекти проблеми : монографія. Дніпропетровськ : Акцент ПП, 2013. 292 с.

15. Ильичева С.А., Заридзе Д.Т. К вопросу о возможных механизмах канцерогенного действия свинца. Вопросы онкологии. 2008. T. 54, № 3. С. 268-271.

16. Агапова Л.С., Копнин Б.П. Прогресс в изучении молекулярных основ онкогенеза и новые способы контроля опухолевого роста. Вестник РАМН. 2007. № 11. С. 3-9.

17. Дурнев А.Д., Середенин С.Б. Мутагены (скрининг и фармакологическая профилактика воздействий). Москва, 1998. 328 с.

18. Хрипач Л.В., Ревазова Ю.А., Рахманин Ю.А. Роль свободнорадикального окисления в повреждении генома факторами окружающей среды. Вестник РАМН. 2004 № 3. С. 16-18.
19. Садогурська К.В., Каплуненко В.Г., Чекман І.C. Хром і нанохром: властивості, перспективи застосування у медичній практиці. Український медичний часопис. 2014. № 1. C. 14-16.

20. Тронько М.Д., Щербак О.В. Мікроелементи в ендокринології. Вісник фармакології та фармації. 2002. № 10.

C. 8-12.

21. Безруков О.Ф. Антропогенное загрязнение как фактор, способствующий возникновению патологии щитовидной железы. Проблемы, достижения и перспективы развития медико-биологических наук и практического здравоохранения : тр. Крым. гос. мед. ун-та им. С.И. Георгиевского. 2007. Т. 143

C. 29-36.

22. Пасечко Н.В., Свистун І.І., Швед Л.В. Комплексна оцінка показників імунного статусу, прооксидантної та антиоксидантної системи у хворих на дифузний токсичний зоб за умов йододефіциту. Клінічна ендокринологія та ендокринна хірургія. 2008. № 2 (23). C. $14-17$

23. Гончарова О.А. Селен и щитовидная железа (обзор литературы и данные собственных исследований)

Ендокринологія. 2014. Т. 19. № 2. С. 149-155.

24. Salnikov K., Zhitkovich A. Genetic and epigenetic mechanisms in metal carcinogenesis and cocarcinogenesis: nickel, arsenic and chromium. Chem. Res. Toxicol. 2008. № 21. P. 28-44.

25. Zhang X., Shuk-Mei Ho Epigenetics meets endocrinology. J. Mol. Endocrinol. 2011. Vol. 46 (1). R11-R32.

26. Baccarelli A., Bollati V. Epigenetics and environmental chemicals. Curr. Opin. Pediatr. 2009. Vol. 21 (2).

P. 243-251.

27. Bugalho M.J.M., Wohllk N., Hoff N.O., Cabanillas M.E. Thyroid oncology. J. of Thyroid Research. 2011. Articl. ID467570. URL : http://dx.doi.org/10.4061 /2011/467570

28. Prazeres H., Torres G., Rodrigues F., Pinto M. Pastoriza M.C., Gomes D., Cameselle-Teijeiro J. et al. Chromosomal, epigenetic and microRNA-mediated inactivation of LRP1B, a modulator of the extracellular environment of thy- roid cancer cells. Oncogene. 2011. Vol. 30 (11). P. 1302 1317.

29. Pogribny I.P. Epigenetic events in tumorigenesis: putting pieces together. Exp. Oncol. 2010. Vol. 32 (3). P. 132-136.

30. Lu H., Shi X., Costa Huang Ch. Carcinogenic effect of nickel compounds. Molecular and Cellular Biochemistry. 2005. № 279. P. 45-67.

31. Зотов А.С. Полинеоплазия: рак щитовидной железы и рак молочной железы - частота, причины, механизмы развития. Проблемы эндокринологии. 2005. Т. 51 (6). С. 50-53.

32. Wright R.O. Biomarkers of Lead Exposure and DNA Methylation within Retrotransposons. Environmental Health Perspectives. 2010. Vol. 118 (6). P. 790-795.

33. Тарасюк О.О., Шишка Т.В., Сидор Л.М. та ін. Деякі аспекти етіології йододефіцитних захворювань. Сучасні проблеми епідеміології, мікробіології та гігієни : матер. наук. -практ. конф. Львів, 2010. С.128-139.

34. Иванов С.Д. Железо как канцерогенный экотоксикант. Токсикологический вестник. 2005. № 2 (102). С. 34-41.

35. Михайлова И.В., Чеснокова Л.В., Шарапова Н.В., Смолягин А.И., Красиков С.И. Некоторые показатели микроэлементного и антиоксидантного статуса крыс при хромовой интоксикации. Гигиена и санитария. 2014. № 3.

С. 71-74.

36. Застенская И.А., Пивень Н.Н., Кочубинская В.В., Кочубинский А.В. Изучение влияния полихлорированных бифенилов и тяжелых металлов на показатели иммунной системы в эксперименте. Токсикологический вестник. 2015. № 2. С. 40-45.

\section{REFERENCES}

1. Litvichenko O.N., Chernichenko I.A. \& Tsimbaliuk S.N. Vliianie prioritetnykh khimicheskikh kantserogenov atmosfernogo vozdukha na zabolevayemost naseleniya rakom shchitovidnoy zhelezy [Effect of the Foreground Chemical Carcinogens of Ambient Air on the Morbidity of Thyroid Gland Cancer among Population]. In : Zdorovie $i$ okruzhayushchaya sreda: sb. nauch. tr. [Health and Environment]. Minsk ; 2015 ; I (25) : 55-58 (in Russian). 
2. Chernychenko I.O., Lytvychenko O.M., Tsymbaliuk S.M., Shvaher O.V., Sovertkova L.S. \& Balenko N.V. Khimichni kantseroheny atmosfernoho povitria: vplyv na zakhvoriuvanist naselennia na rak shchytopodibnoi zalozy [Chemical Carcinogens of Ambient Air: Influence on the Population Morbidity of Thyroid Gland Cancer]. In : Hihiiena naselenykh mists: zb. nauk. prats [Hygiene of the Settlements: Coll.Sci.Works]. Kyiv; 2015; 66 : 104-110 (in Ukrainian).

3. Baskov A.Ya. \& Tulenkov N.V. Metodologiya nauchnogo issledovaniya [Methodology of Scientific Research]. Kiev ; 2004 : 215 p. (in Russian).

4. Serdiuk A.M., Beletskaia E.N., Paranko N.M. \& Shmatkov G.G. Tiazhelye metally vneshnei sredy i ikh vliyaniye na reproduktivnuiu funktsiyu zhenshchin [Environmental Heavy Metals and their Effect on the Reproductive Function of Women]. Dnepropetrovsk : Art-Press ; 2004 : 148 p. (in Russian).

5. Trakhtenberg I.M. Dovkillia ta zdorovia. $1997 ; 2: 48-51$ (in Russian).

6. Rom W.N. (ed.). Environmental and Occupational Medicine. Philadelfia - New-York; 1998 : 1437 p.

7. JARC Monographs on the Evaluation of the Carcinogenic Risks to Humans. Arsenic, Metals, Fibers and Dusts. Lyon: IARC; 2012; $100: 41-467$.

8. Kurliandskiy B.A. \& Filov V.A. (eds.). Obshchaya toksikologiya [ General Toxicology]. Moscow : Meditsina ; 2002 : 608 p. (in Russian).

9. Trankhtenberg I.M., Kolesnikov V.S. \& Lukovenko V.P. Tiazhelye metally vo vneshnei srede: sovremennyie gigienicheskie i toksikologicheskie aspekty [Heavy Metals in the Environment: Modern Hygienic and Toxicological Aspects ]. Minsk : Nauka i tekhnika; 1994 : 285 p. (in Russian).

10. Trakhtenberh I.M., Chekman I.S., Lynnyk V.O., Kaplunenko V.H., Hulich M.P., Biletska E.M., Shatorna V.F. \& Onul N.M. Visnyk NAN Ukrainy. 2013 ; 6 : 11-20 (in Ukrainian).

11. Dmytrukha N.M. Ukrainskyi zhurnal z problem medytsyny pratsi. 2010 ; № 2(22) : 36-41 (in Ukrainian).

12. Petrynych V.V. Kharakter toksychnykh efektiv u shchuriv z riznoiu shvydkistiu atsetyliuvannia za umov pidhostroho vplyvu marhantsiu khlorydu i svyntsiu atsetatu ta profilaktyka za dopomohoiiu kvertsetynu : avtoref. dys. ... kand. med. nauk

[Character of the Toxic Effects in Rats with a Different Rate of Acetylation under Conditions of Subacute Effect of Manganese Tetrachloride and Lead Acetate and Quercitin Prophylaxis : Abs. Thes. Cand. Med. Sci.]. Kyiv, 2013. 22 p. (in Ukrainian).

13. WHO/UNEP State of the Science of Endocrine Disrupting Chemicals. 2012 : An assessment of the state of the science of endocrine disruptors prepared by a group of experts for the United Nations Environment Programme (UNEP) and WHO. URL : http://www.who.int/ceh/ publications/endocrine/en/

14. Biletska E.M. \& Onul N.M Selen u dovkilli: ekoloho-hihienichni aspekty problemy : monohrafiia [Selenium in the Environment: Ecologic-and-Hygienic Aspects of the Problem : Monograph].

Dnipropetrovsk : Aktsent ; 2013 :

292 p. (in Ukrainian).

15. llicheva S.A. \& Zaridze D.T. Voprosy onkologii. $2008 ; 54(3)$ : 268-271 (in Russian).

16. Agapova L.S. \& Kopnin B.P. Vestnik RAMN. 2007 ; 11 : 3-9 (in Russian).

17. Durnev A.D. \& Seredenin S.B. Mutageny (skrining i farmakologicheskaya profilaktika vozdeistviy) [Mutagens (Screening and Pharmacological Prophylaxis)]. Moscow ; 1998 : 328 p. (in Russian).

18. Khripach L.V., Revazova

Yu.A. \& Rakhmanin Yu.A. Vestnik RAMN. 2004 ; 3 : 16-18 (in

Russian).

19. Sadohurska K.V., Kaplunenko V.H. \& Chekman I.S. Ukrainskyi medychnyi chasopys. 2014 ; 1 : 14-16 (in Ukrainian).

20. Tronko M.D. \& Shcher-

bak O.V. Visnyk farmakolohii ta farmatsii. 2002 ; $10: 8-12$ (in Ukrainian).

21. Bezrukov O.F. Antropogennoye zagriazneniye kak faktor, sposobstvuiushchiy vozniknoveniyu patologii shchitovidnoy zhelezy [Anthropogenic Contamination as a Factor of the Beginning of Thyroid Gland Pathology]. In: Problemy, dostizheniya i perspektivy razvitiya mediko-biologicheskikh nauk $i$ prakticheskogo zdravookhraneniya [Problems, Achievements, and Perspectives of the Development of MedicoBiological Sciences and
Practical Public Health]. 2007 ; 143 : 29-36 (in Russian).

22. Pasechko N.V., Svystun I.I. \& Shved L.V. Klinichna endokrynolohiia ta endokrynna khirurhiia. 2008 ; 2 (23) : 14-17 (in Ukrainian).

23. Goncharova O.A.

Endokrinologiya. 2014 ; 19(2) : 149-155 (in Russian).

24. Salnikov K. \& Zhitkovich A Chem. Res. Toxicol. 2008 ; 21 : 28-44.

25. Xiang Zhang \& Shuk-Mei Ho J. Mol. Endocrinol. 2011 ; 46 (1) : R11-R32.

26. Baccarelli A. \& Bollati V. Curr. Opin. Pediatr. 2009 ; 21(2) : 243-251.

27. Bugalho M.J.M., Wohllk N., Hoff N.O. \& Cabanillas M.E. J. of Thyroid Research. 2011 ; Articl. ID467570. Available at :

http://dx.doi.org/10.4061/2011/ 467570

28. Prazeres H., Torres G., Rodrigues F., Pinto M., Pastoriza M.C., Gomes D., CameselleTeijeiro J. et al. Oncogene. 2011 ; 30 (11) : 1302-1317.

29. Pogribny I.P. Exp. Oncol. 2010 ; 32 (3) : 132-136.

30. Lu H., Shi X., Costa M. \&

Huang Ch. Molecular and Cellular Biochemistry. 2005 ; 279: 45-67.

31. Zotov A.S. Problemy endokrinologii. 2005 ; 51(6) :

50-53 (in Russian).

32. Wright R.O. Environmental Health Perspectives. 2010 ; 118 (6) : 790-795.

33. Tarasiuk O.O., Shyshka T.V., Sydor L.M. et al. Deiaki aspekty etiolohii iododefitsytnykh zakhvoriuvan [Some Aspects of the Aetiology of lodine

Deficiency Diseases]. In: Suchasni problemy epidemiolohii, mikrobiolohii ta hihiieny: mater. nauk.-prakt. konf. [Modern Problems of Epidemiology, Microbiology, and Hygiene : Mater. Sci.-Pract. Conf.] Lviv; 2010 : 128-139

(in Ukrainian).

34. Ivanov S.D. Toksikologicheskiy vestnik. 2005 ; 2(102) : 34-41 (in Russian).

35. Mikhailova I.V., Chesnokova L.V., Sharapova N.V.,

Smoliagin A. I. \& Krasikov S.I. Gigiiena i sanitariia. 2014 ; 3 : 71-74 (in Russian).

36. Zastenskaia I.A.,

Piven N.N., Kochubinskaia V.V. \& Kochubinskiy A.V.

Toksikologicheskiy vestnik. 2015 ; 2 : 40-45 (in Russian).

Надійшла до редакції 08.02.2017 